OPEN ACCESS

Edited by:

Joanna Mucha

Institute of Dendrology (PAN), Poland

Reviewed by:

Enrique Andivia,

Complutense University of

Madrid, Spain

Cameron Ducayet Mclntire,

United States Forest Service (USDA),

United States

*Correspondence:

Sue J. Grayston

sue.grayston@ubc.ca

Specialty section:

This article was submitted to

Forest Ecophysiology,

a section of the journal

Frontiers in Forests and Global

Change

Received: 22 September 2020 Accepted: 10 December 2020

Published: 12 January 2021

Citation:

Churchland $C$, Bengtson $P$, Prescott CE and Grayston SJ (2021)

Dispersed Variable-Retention

Harvesting Mitigates N Losses on Harvested Sites in Conjunction With

Changes in Soil Microbial Community

Structure.

Front. For. Glob. Change 3:609216.

doi: 10.3389/ffgc.2020.609216

\section{Dispersed Variable-Retention} Harvesting Mitigates N Losses on Harvested Sites in Conjunction With Changes in Soil Microbial Community Structure

\author{
Carolyn Churchland ${ }^{1}$, Per Bengtson ${ }^{2}$, Cindy E. Prescott ${ }^{1}$ and Sue J. Grayston ${ }^{1 *}$ \\ ${ }^{1}$ Belowground Ecosystem Group, Department of Forest Sciences, University of British Columbia, Vancouver, BC, Canada, \\ ${ }^{2}$ Department of Biology-Microbial Ecology, Lund University, Lund, Sweden
}

As an alternative to clear-cutting, variable-retention harvesting is now standard forest management practice on the coast of British Columbia and in temperate forests globally, due to the benefits associated with maintaining mature forest species and forest structural diversity. Although there is some evidence that variable-retention harvesting, particularly single-tree (dispersed) retention will mitigate the impacts of clear-cutting on soil microbial communities and nutrient cycling, findings have been inconsistent. We examined microbial community structure (phospholipid-fatty acid), and nutrient availability ( $\mathrm{PRS}^{\mathrm{TM}}$ probes) in a large (aggregated) retention patch and over three harvesting treatments: dispersed retention, clear-cut and clear-cut edge 2 years after harvest. Unlike previous studies, we did not observe elevated nitrate in the harvested areas, instead ammonium was elevated. Availability of $\mathrm{N}$ and other nutrients were surprisingly similar between the dispersed-retention treatment and the retention patch. The microbial community, however, was different in the clear-cut and dispersed-retention treatments, mostly due to significantly lower abundance of fungi combined with an increase in bacteria, specifically Gram-negative bacteria. This was accompanied by lower $\delta^{13} \mathrm{C}_{\mathrm{PDB}}$ value of the Gram-negative PLFA's in these treatments, suggesting the decline in mycorrhizal fungal abundance may have allowed the dominant Gram-negative bacteria to access more of the recently photosynthesized $\mathrm{C}$. This shift in the microbial community composition in the dispersed-retention treatment did not appear to have a major impact on microbial functioning and nutrient availability, indicating that this harvesting practice is more effective at maintaining generic microbial functions/processes. However, as Mn levels were twice as high in the retention patch compared to the harvested treatments, indicating the other "narrow" processes (i.e., those performed by a small number of specialized microorganisms), such as lignin degradation, catalyzed by Mn peroxidase, which concomitantly removes Mn from solution, may be more sensitive to harvesting regimes. The effect of harvesting on such narrow nutrient cycling processes requires further investigation.

Keywords: variable-retention harvesting, microbial community structure, nitrogen, Mn, soil respiration, PLFA 


\section{INTRODUCTION}

Variable-retention harvesting (VRH), as opposed to clear-cut harvesting, is being employed in many contexts because of the perceived ecological benefits. The goals of VRH (also known as green-tree retention or just retention harvesting) are to maintain forest structural diversity, preserve species associated with mature forests, and support faster post-harvest recovery of biodiversity (Franklin et al., 1997, 2018). The benefits of retaining aboveground tree and shrub species for the preservation of plant and animal diversity are well-documented in the short term (Work et al., 2003; Atwell et al., 2008; Aubry et al., 2009), particularly for ground-dwelling animals and epiphytic lichens (Rosenvald and Lõhmus, 2008). Although not as welldocumented, there is reason to believe that VRH will impart similar benefits to belowground biodiversity and function. The trees retained on clear-cut sites are thought to act as "lifeboats" for microbes, maintaining belowground plant-soil interactions and ensuring seedlings will have access to hostspecific mycorrhizae and microbes, which could aid seedling success (Franklin et al., 1997; Beese et al., 2019). Belowground plant-soil interactions have been increasingly recognized as necessary to ecosystem functioning (Bever et al., 1997; Wardle et al., 2004; Bardgett et al., 2005), and are considered a key knowledge gap and a major research challenge for retention forestry (Gustafsson et al., 2012).

Harvesting of trees changes the quality and decreases the quantity of plant C inputs into the soil (Marshall, 2000), and affects soil temperature, moisture, $\mathrm{pH}$, and available nitrogen (Covington, 1981; Chen et al., 1995; Hassett and Zak, 2005; Nave et al., 2010). Generally, clear-cut harvesting is followed by a period of increased availability of soil nutrients (Keenan and Kimmins, 1993); particularly nitrate $\left(\mathrm{NO}_{3}^{-}\right)$(Gordon and Van Cleve, 1983; Mladenoff, 1987; Fisk and Fahey, 1990; Denslow et al., 1998; Gravelle et al., 2009; Jerabkova et al., 2011). Nitrate levels typically increase within a year of clear-cut harvesting, and remain elevated for 3-5 years (Prescott et al., 2003). However, this depends on site fertility (Vitousek et al., 1979) and the forest type, as the response in coniferous forests tends to be delayed, but prolonged, relative to deciduous forests (Futter et al., 2010; Jerabkova et al., 2011). Other studies have found that $\mathrm{NO}_{3}^{-}$levels remain low after harvesting (Barg and Edmonds, 1999; Bock and van Rees, 2002; Jerabkova et al., 2006; Jerabkova and Prescott, 2007); instead, ammonium $\left(\mathrm{NH}_{4}^{+}\right)$levels increase relative to uncut forests (Carmosini et al., 2002; Titus et al., 2006; Bradley and Parsons, 2007; Theil and Perakis, 2009). At the edges of clearcuts (within $11 \mathrm{~m}$ of the forest edge), nitrogen availability tends to resemble that in the adjacent forest (Hope et al., 2003; Jerabkova et al., 2006; Theil and Perakis, 2009).

Variable-retention harvested areas have been shown to have nutrient and microclimate conditions intermediate to uncut and clear-cut forests (Barg and Edmonds, 1999; Lajzerowicz et al., 2004; Lapointe et al., 2005; Marenholtz et al., 2010), with elevated $\mathrm{NO}_{3}^{-}$levels (relative to uncut forest sites) reported in openings as small as 0.07 to 1.7 hectares (Prescott et al., 1992, 2003; Parsons et al., 1994; Bauhus and Bartsch, 1995; Prescott, 2002; Hope et al., 2003). Single-tree retention appears to have little effect on soil nitrogen availability, even when up to $60 \%$ of trees are removed (Knight et al., 1991; Parsons et al., 1994; Hope et al., 2003; Prescott et al., 2003; Redding et al., 2003; Jerabkova et al., 2011). This muted effect can be attributed to the residual trees continuing to take up soil $\mathrm{N}$, minimizing environmental extremes by providing shade, maintaining more consistent soil moisture and pH (Carlson and Groot, 1997; Franklin et al., 1997; Jerabkova et al., 2011), and maintaining inputs of C through litter and root exudates (Lee et al., 2002).

The impact of forest harvesting on soil microbes is less wellestablished (Siira-Pietikäinen et al., 2001; Hernesmaa et al., 2005). Soil microbial biomass has been reported to increase (Sundman et al., 1978; Entry et al., 1986), decrease (Bradley et al., 2001; Siira-Pietikäinen et al., 2001; Moore-Kucera and Dick, 2008; Mummey et al., 2010), or remain the same (Smolander et al., 1998; Barg and Edmonds, 1999; Li et al., 2004) following clearcut harvesting. The impact of clear-cut harvesting on microbial community composition is similarly inconsistent. Microbial community composition may not change (Ponder and Tardos, 2002; Hannam et al., 2006); bacteria (Moore-Kucera and Dick, 2008), specifically Gram-negative bacteria (Mummey et al., 2010) and Actinobacteria (Hartmann et al., 2009) may be reduced; but more commonly fungal biomass is reduced (Mummey et al., 2010) and the fungal community composition is altered, particularly ratios of ectomycorrhizal and saprotrophic genera (Jones et al., 2003; Hartmann et al., 2009, 2012). Fewer studies have examined the impact of VRH on the microbial community, and results are not in agreement; soil microbial biomass may be reduced (Lindo and Visser, 2003) or unaffected in openings relative to retention patches (Churchland et al., 2013). Chatterjee et al. (2008) observed a reduction of fungi and Gram-negative bacteria in harvested areas. Similarly Luoma et al. (2006) reported a decrease in ectomycorrhizal richness with increasing distance from retention patches. Single-tree removal has been found to mitigate changes to the microbial community structure (Kranabetter and Wylie, 1998; Hagerman et al., 1999), although changes in the fungal community, particularly ectomycorrhizae, still occur (Kropp and Albee, 1996; Buée et al., 2005; Teste et al., 2012; Bach et al., 2013).

Retaining live trees on harvested sites provides soil organisms with a continually replenished source of labile carbon (C) from root exudates (Högberg et al., 2001; Zak et al., 2003), as well as above- and below-ground litter materials. Recently photosynthesized labile plant $\mathrm{C}$ exuded by roots is typically ${ }^{13} \mathrm{C}$-depleted relative to older $\mathrm{C}$ stored in coarse woody debris and soil organic matter (Kuzyakov, 2006; Werth and Kuzyakov, 2010). Natural variation in these carbon sources can be used to infer the flow of $\mathrm{C}$ in the environment (Schweizer et al., 1999). By comparing the ratio ${ }^{13} \mathrm{C} /{ }^{12} \mathrm{C}$ within microbial signature phospholipid fatty acids to that of other $\mathrm{C}$ pools, including recently photosynthesized C, it is possible to determine which microbial groups rely on recently photosynthesized $\mathrm{C}$ from living trees for growth.

The objective of this study was to determine whether aggregated-retention harvesting (where living trees are retained in aggregated patches) or dispersed variable-retention harvesting 
(where single dispersed individuals are retained) best maintains pre-harvest soil microbial community structure and soil nutrient availability. In addition, through analysis of $\delta^{13} \mathrm{C}_{\mathrm{PDB}}$ values in the microbial community we could deduce which microorganisms are dependent on plant photosynthate for growth. In order to meet these objectives we used principle component analysis (PCA) to examine nutrient availability and ${ }^{13} \mathrm{C}$ natural abundance stable-isotope ratios of soil microbial phospholipid fatty acids (PLFA) in a second-growth forest, along a clear-cut edge, in a clear-cut and in a dispersed-retention harvested area, 2 years following harvesting. Soil nutrient availability at each point was estimated using plant root simulator (PRS) probes.

\section{MATERIALS AND METHODS}

\section{Study Site}

Samples were collected in the third replicate of the existing Silviculture Treatments for Ecosystem Management in the Sayward (STEMS) long-term research installation set up by the British Columbia Ministry of Forests and Range, close to Gray Lake on Vancouver Island, B.C. $\left(50^{\circ} 03^{\prime} 43.02^{\prime \prime} \mathrm{N}\right.$, $\left.125^{\circ} 35^{\prime} 24.35^{\prime \prime} \mathrm{W}\right)$ in early May, 2009. The stand is in a submontane very dry maritime Coastal Western Hemlock biogeoclimatic zone (CWHxm2) (de Montigny, 2004; de Montigny et al., 2018), receives annual precipitation of $\sim 1,529.5 \mathrm{~mm}$ has and has a mean temperature of $8.4^{\circ} \mathrm{C}$ (National Climate data and information archive, 1971-2000). Soils are mostly Orthic Humo-Ferric Podzols with moder humus form and sandy-loam structure (de Montigny et al., 2018).

The second-growth stand histories across the STEMS 3 experimental site are similar. Prior to harvest, Douglas-fir accounted for more than $90 \%$ of the total volume across all treatment units; minor components of western hemlock, western redcedar, western white pine, and/or red alder were present (de Montigny et al., 2018). At the pre-harvest measurement in 2006, treatment units ranged in density from $286 \mathrm{sph}$ in the dispersed retention area to $549 \mathrm{sph}$ in the aggregated retention area. Basal area was $33.7 \mathrm{~m}^{2} /$ ha in the dispersed retention area and 38.4 $\mathrm{m}+/ \mathrm{ha}$ in the aggregated retention area. In February 2008 the existing 60-70-year-old stands were harvested using variableretention, retaining trees in both aggregated and dispersed formats. Aggregate-retention patches, within which all the trees (Douglas-fir dominant and minor western redcedar component) were retained, ranged from 0.21 to 1.65 ha in size, totaling 4.86 ha in 14 patches, with clear-cut spaces ranging from 4.4 to 11.5 ha, in a total area of 35.0 ha. In the dispersed-retention treatment, approximately 45 trees per ha were retained within a 37.8-ha area (de Montigny et al., 2018). Douglas-fir and western red cedar (Thuja plicata) seedlings were planted in March 2009. The ground vegetation consisted mainly of salal (Gaultheria shallon) and sword fern (Polystichum munitum). The soils were a mix of mineral and organic layers in the harvested areas due to soil disturbance during harvesting; those areas that were not mixed had a forest floor $6-8 \mathrm{~cm}$ deep. The soil $\mathrm{pH}$ ranged from 3.5 to 5.0 .

\section{Soil Sampling}

Two equally distributed $10 \times 10$ point grids with sampling points $3 \mathrm{~m}$ apart in the north-south direction and $2 \mathrm{~m}$ apart in the east-west direction were laid out, one within the dispersedretention area and the other positioned on the northern edge of an aggregate-retention patch such that it extended $12 \mathrm{~m}$ south into the aggregated-retention patch, and $15 \mathrm{~m}$ north into the clear-cut area. At each sampling point, three soil cores were collected using a 5-cm-diameter stainless-steel corer to a depth of $10 \mathrm{~cm}$. The three cores were combined and stored at $4^{\circ} \mathrm{C}$ within $6 \mathrm{~h}$. The soil was sieved to $<2 \mathrm{~mm}$ prior to PLFA analysis.

Samples from the study area (dispersed-retention and aggregated-retention) were separated into four treatments for comparison. Samples from the five southernmost rows in the aggregated-retention area, located at the edge and extending $12 \mathrm{~m}$ into the patch of retained trees, were considered part of the retention patch (RP, 50 samples). Samples along the next two rows, just north of the retention patch, located 3 and $6 \mathrm{~m}$ into the clear-cut, were considered clear-cut edge (CCE, 20 samples). The three northernmost rows of samples at the aggregateretention area, between 9 and $15 \mathrm{~m}$ from the retention patch, were denominated clear-cut (CC, 30 samples). The division into CCE and CC was based on prior knowledge from this particular site, and from other studies that have demonstrated that the influence of trees on belowground communities and processes are greatest within $10 \mathrm{~m}$ of the trees (Saetre, 1999; Saetre and Bååth, 2000; Bengtson et al., 2006; Churchland et al., 2013; Chapter 3 this thesis). Samples collected from the dispersed-retention site (DR) were not separated (100 samples).

\section{Soil Physical, Biological, and Chemical Analysis}

Phospholipid fatty acids were extracted according to the Frostegård et al. (1991) method, based upon the Bligh and Dyer (1959) procedure, and further modified by White et al. (1979). Briefly, soil samples (1.2 g of freeze-dried soil) were vortexextracted in a 0.8:1:2(v/v/v) solution of citrate buffer, chloroform and methanol. The extracted lipids were then fractionated into neutral lipids, glycolipids, and phospholipids on Accubond II Solid Phase Extraction silica columns (Agilent Technologies Inc., Santa Clara, CA) by elution with chloroform, acetone, and methanol. A known amount of methyl nonadecanoate (19:0) was added to the fraction containing the phospholipids to act as an internal standard. Lipids were then transmethylated to their fattyacid methyl esters using mild alkaline methanolysis. Following this fatty-acid residues were flash-evaporated under $\mathrm{N}_{2}$-gas and stored at $-20^{\circ} \mathrm{C}$ until analysis.

PLFA peaks were identified by means of a combination of mass spectra and retention times relative to the internal standard 19:0, and an external bacterial acid methyl-ester standard (BAME; Sigma-Aldrich co., 47080-U, Oakville, ON, Canada). PLFA ${ }^{12} \mathrm{C} /{ }^{13} \mathrm{C}$ were analyzed with a Gas Chromatograph (Agilent Technologies Gas Chromatograph 6890N, Santa Clara, CA, United States), interfaced with a combustion furnace (GV instrument GC5 MK1) in turn interfaced with a Isoprime ratio mass spectrometer (GV instrument, both Cheadle Hulme, 
TABLE 1 | Abundance (mol \%) of PLFAs in the clear-cut treatment, the clear-cut edge treatment (within $9 \mathrm{~m}$ of the retention patch), the retention patch and the dispersed-retention treatment.

\begin{tabular}{|c|c|c|c|c|c|c|c|c|}
\hline & \multicolumn{2}{|c|}{ Clear-cut } & \multicolumn{2}{|c|}{ Clear-cut edge } & \multicolumn{2}{|c|}{ Retention patch } & \multicolumn{2}{|c|}{ Dispersed retention } \\
\hline & Mean & SE $(n=30)$ & Mean & SE $(n=20)$ & Mean & SE $(n=50)$ & Mean & SE $(n=100)$ \\
\hline i15 & 8.5 & 0.4 & 7.6 & 0.4 & 7.2 & 0.3 & 7.3 & 0.2 \\
\hline a15 & 3.3 & 0.1 & 3.1 & 0.1 & 2.7 & 0.1 & 3.2 & 0.1 \\
\hline iC16:0 & 4.0 & 0.3 & 3.4 & 0.2 & 3.4 & 0.2 & 4.1 & 0.2 \\
\hline$C 16: 1 \omega 7 c$ & 9.1 & 0.2 & 8.4 & 0.3 & 8.3 & 0.2 & 8.2 & 0.1 \\
\hline 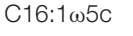 & 3.5 & 0.1 & 3.4 & 0.1 & 3.1 & 0.1 & 3.5 & 0.1 \\
\hline C16:0 & 16.5 & 0.8 & 17.8 & 0.6 & 17.6 & 0.4 & 15.7 & 0.4 \\
\hline i17:1 $1 \omega 8 \mathrm{c}$ & 2.1 & 0.1 & 1.9 & 0.1 & 1.8 & 0.1 & 2.4 & 0.1 \\
\hline 10Me17:0 & 6.5 & 0.4 & 6.1 & 0.4 & 5.5 & 0.3 & 6.7 & 0.2 \\
\hline iC17:0 & 1.4 & 0.1 & 1.3 & 0.0 & 1.2 & 0.1 & 1.6 & 0.1 \\
\hline aC17:0 & 1.6 & 0.1 & 1.7 & 0.1 & 1.6 & 0.1 & 1.9 & 0.1 \\
\hline 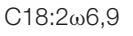 & 6.5 & 0.4 & 8.5 & 0.8 & 11.1 & 0.4 & 7.2 & 0.3 \\
\hline C18:1w9c & 11.4 & 0.2 & 12.5 & 0.3 & 11.8 & 0.4 & 10.5 & 0.2 \\
\hline 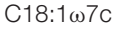 & 12.5 & 0.5 & 11.2 & 0.4 & 11.7 & 0.3 & 12.1 & 0.3 \\
\hline C18:0 & 3.0 & 0.1 & 3.0 & 0.1 & 2.7 & 0.1 & 3.3 & 0.1 \\
\hline cy19:0 & 10.3 & 0.6 & 10.0 & 0.5 & 10.4 & 0.4 & 12.3 & 0.4 \\
\hline
\end{tabular}

SE represents standard error of the means.

United Kingdom) at the Belowground Ecosystem Group Stable Isotope Facility in the Faculty of Forestry at the University of British Columbia. Sample batches were two-point calibrated to 20:0 isotopic standards that bracketed the expected range of $\delta^{13} \mathrm{C}_{\mathrm{PDB}}$ values (20:0's equaled $-30.68 \%$, standard deviation $0.02 \%$ vs. VPDB, and $-6.91 \%$, standard deviation $0.04 \%$ vs. VPDB; isocanoic acid methyl ester, certified reference material, Indiana University). The following fatty acids were chosen to represent bacterial PLFAs: i15:0, a15:0, 15:0, i16:0, 16:1 $1 \omega 7 \mathrm{c}$,

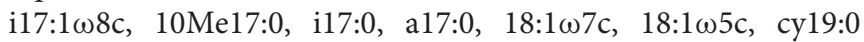
(Kroppenstedt, 1985; Frostegård et al., 1993; Zogg et al., 1997). The branched PLFAs i15:0, a15:0, i16:0, i17:0, and a17:0 were considered to be indicative of Gram-positive bacteria, and $16: 1 \omega 7 c, 18: 1 \omega 7 c$, and cy19:0 of Gram-negative bacteria.

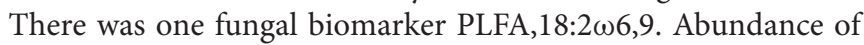
identified fatty acids are expressed as nmols per gram of freezedried soil (nmols $\mathrm{g}^{-1}$ ). Total microbial biomass was calculated as the sum of all PLFAs listed in Table $\mathbf{1 .}$

Three sets of anion and cation Plant Root Simulator $(\mathrm{PRS})^{\mathrm{TM}}$ available-nutrient probes (Western Ag innovations) were incubated in the upper $10 \mathrm{~cm}$ of the soil $2-5 \mathrm{~cm}$ apart, at each of the sampling locations within the retention sites for 90 days. After removal the probes were washed with distilled and deionized water and scrubbed with a stiff brush to remove any residual soil before being shipped to Western Ag Innovations Inc. Laboratory in Saskatoon, Saskatchewan for chemical analysis (Hangs et al., 2004). The following cations and anions were analyzed: $\mathrm{NO}_{3}^{+}, \mathrm{NH}_{4}^{-}, \mathrm{Ca}^{2+}, \mathrm{Mg}^{2+}, \mathrm{K}^{+}, \mathrm{H}_{2} \mathrm{PO}_{4}^{-}, \mathrm{Fe}^{3+}, \mathrm{Mn}^{2+}$, $\mathrm{Cu}^{2+}, \mathrm{Zn}^{2+}, \mathrm{B}^{3+}, \mathrm{SO}_{4}^{2-}, \mathrm{Pb}^{2+}, \mathrm{Al}^{3+}$. The three (PRS) ${ }^{\mathrm{TM}}$ probes at each sampling location were analyzed together, making one composite sample (200 samples in total). Values express the nutrient absorbed per surface area of the ion exchange membrane
( $\mu \mathrm{g}$ of ion/10 $\mathrm{cm}^{2}$ ) (Qian and Schoenau, 2002; Hangs et al., 2004) over 90 days.

\section{Statistical Analysis}

Variations in microbial community composition and nutrient availability among harvesting treatments were assessed by a principal component analysis of the relative abundance (mol \%) of the different PLFAs and the concentrations of nutrients in the PRS probes, respectively. The factor scores for the samples in the different treatments were then used in a Kruskall-Wallis ANOVA by ranks followed by twotailed multiple comparison of means, in order to determine if microbial community composition and nutrient availability were significantly affected by the treatments. The same tests (Kruskall-Wallis ANOVA by ranks followed by a two-tailed multiple comparison of means) was used to assess treatment differences in the other measured variables. All statistical analyses were performed in STATISTICA, version 11 (StatSoft, Inc. Tulsa, OK, United States).

\section{RESULTS}

\section{Microbial Biomass and Community Composition}

Total microbial biomass did not differ between treatments (Figure 1, Kruskal-Wallis ANOVA by ranks, $p=0.66$, $\mathrm{H}=1.59$, d.f. $=3$ ). However, PCA of the PLFA data indicated a clear difference in microbial community composition between the retention patch and the dispersed retention treatment, and between the clear-cut and the clear-cut edge treatments (Figure 2A, Kruskal-Wallis ANOVA by ranks, $p<0.001, \mathrm{H}=18.48$, d.f. $=3$ ). The first principal 


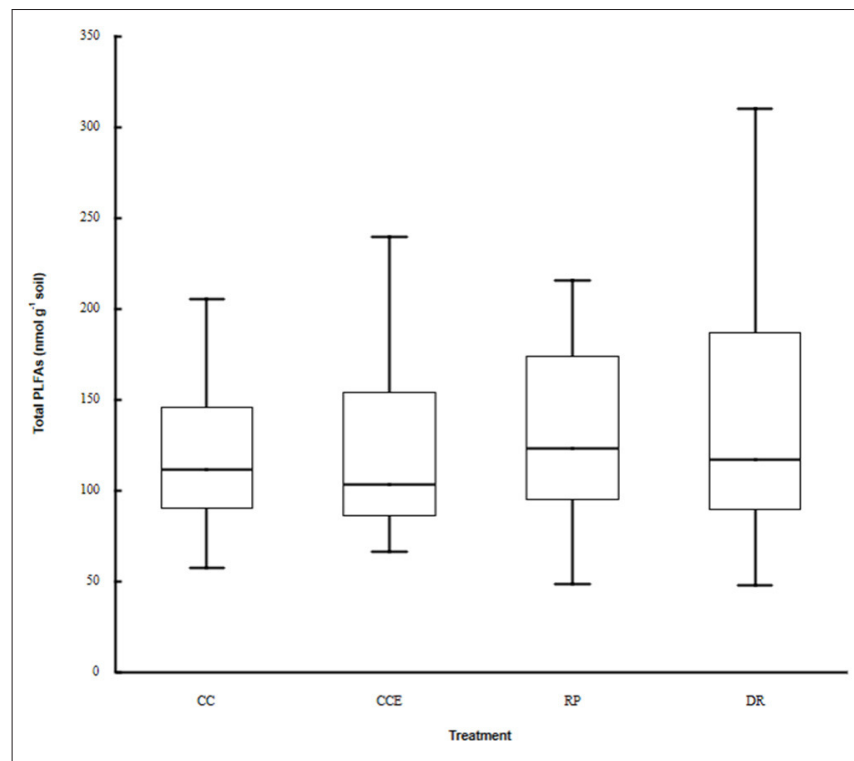

FIGURE 1 | Total microbial biomass in the dispersed retention (DR) treatment, the retention patch $(\mathrm{RP})$, in the clear-cut treatment $(\mathrm{CC}, 9 \mathrm{~m}$, or more from the retention patch) and in the clear-cut edge treatment (CCE, within $9 \mathrm{~m}$ of the retention patch).

component, which explained $44 \%$ of the variation, separated samples from the retention patch, clear-cut edge, and clearcut treatments, from samples taken in the dispersed-retention treatment (Figure 2A). The second principal component, which explained $17 \%$ of the variation, grouped together samples from within the retention patch and samples from the dispersedretention treatments and also grouped together samples from the clear-cut edge and clear-cut treatments. Fungal PLFA abundance was significantly reduced in the clear-cut and clear-cut edge compared to the retention patch $(p<0.001$, $\mathrm{H}=21.34$, d.f. $=3$ ).

The differences in microbial community composition between the treatments was mostly the result of the lower abundance of

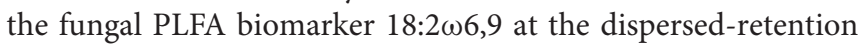
treatment ( $p<0.001, \mathrm{H}=21.34$, d.f. $=3$, Figure 2B, Table 1). The abundance of $18: 2 \omega 6,9$ was highest in the retention patch and lowest in the clear-cut treatment, with the clear-cut edge and dispersed-retention treatments being intermediate $(p<0.001, \mathrm{H}$ $=21.34$, d.f. $=3$, Table 1 ). Compared to the retention patch, the abundance of $\mathrm{C} 18: 2 \omega 6,9$ decreased by $35.1,23.4$, and $41.4 \%$ in the DR, CCE, and CC, respectively. The decrease in fungal abundance in the dispersed-retention area co-occurred with an increase in the relative abundance of the Gram-negative PLFA biomarker cy19:0 $(p<0.05, \mathrm{H}=10.90$, d.f. $=3$, Table 1$)$. The abundance of cy19:0 increased by $18.3 \%$ in the dispersedretention area compared to the retention patch, abundance of cy19:0 remained similar to the retention patch in the clearcut and clear-cut edge treatments. In fact, the reduced fungal abundance due to tree harvesting seemed to generally be associated with increased bacterial abundance (Figure 3).

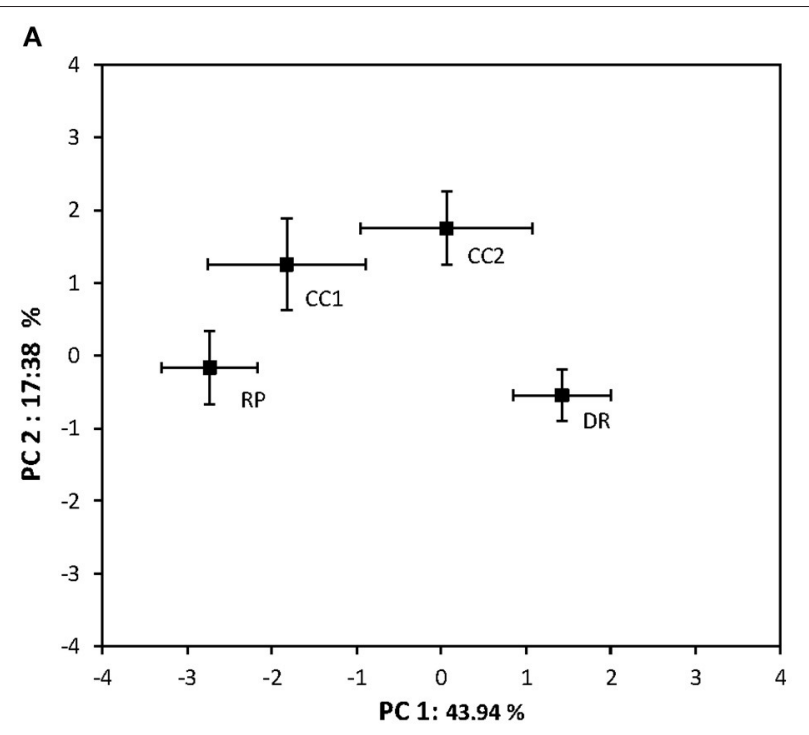

B

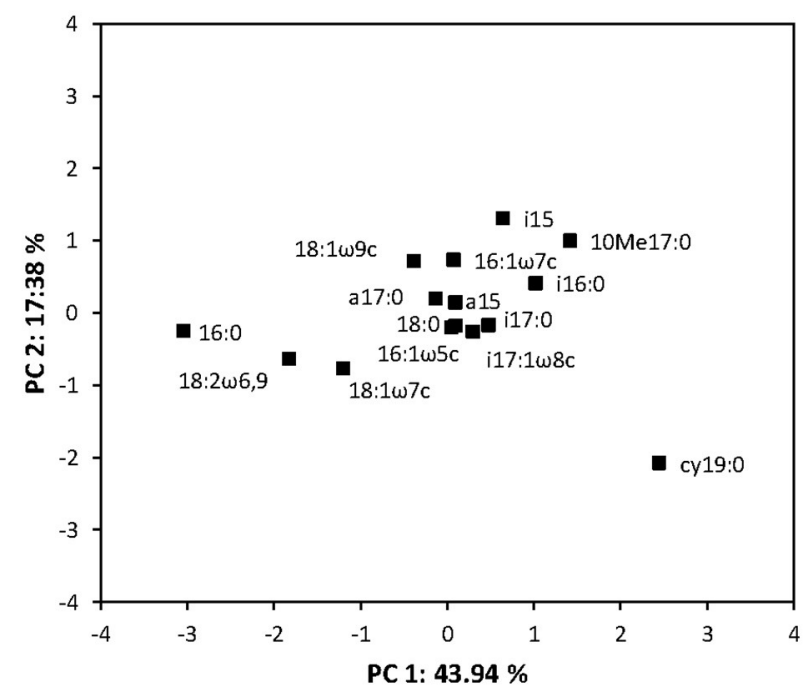

FIGURE 2 | Principal component analysis ordination showing (A) soil microbial communities based on PLFA abundance (mol\%) in the dispersed-retention $(\mathrm{DR})$ treatment, the retention patch (RP), in the clear-cut treatment (CC, $9 \mathrm{~m}$, or more from the retention patch) and in the clear-cut edge treatment (CCE, within $9 \mathrm{~m}$ of the retention patch). (B) The relative contributions of individual PLFAs to the community structure. Horizontal and vertical error bars represent standard error.

\section{$\delta^{13} C_{\text {PDB }}$ Values of Microbial PLFAs}

The weighted average $\delta^{13} C_{\mathrm{PDB}}$ values of PLFA biomarkers were significantly lower in the retention patch relative to the clearcut treatment (Figure 4, $p<0.001$ ), with the clear-cut edge treatment being intermediate to these. This trend was also observed in the $\delta^{13} \mathrm{C}_{\mathrm{PDB}}$ values of fungal as well as Gramnegative and Gram-positive biomarker PLFAs (Figure 4). The weighted-average $\delta^{13} \mathrm{C}_{\mathrm{PDB}}$ values of PLFA biomarkers in samples from the dispersed-retention treatment were generally similar to samples from the retention patch. For fungi the ANOVA showed 


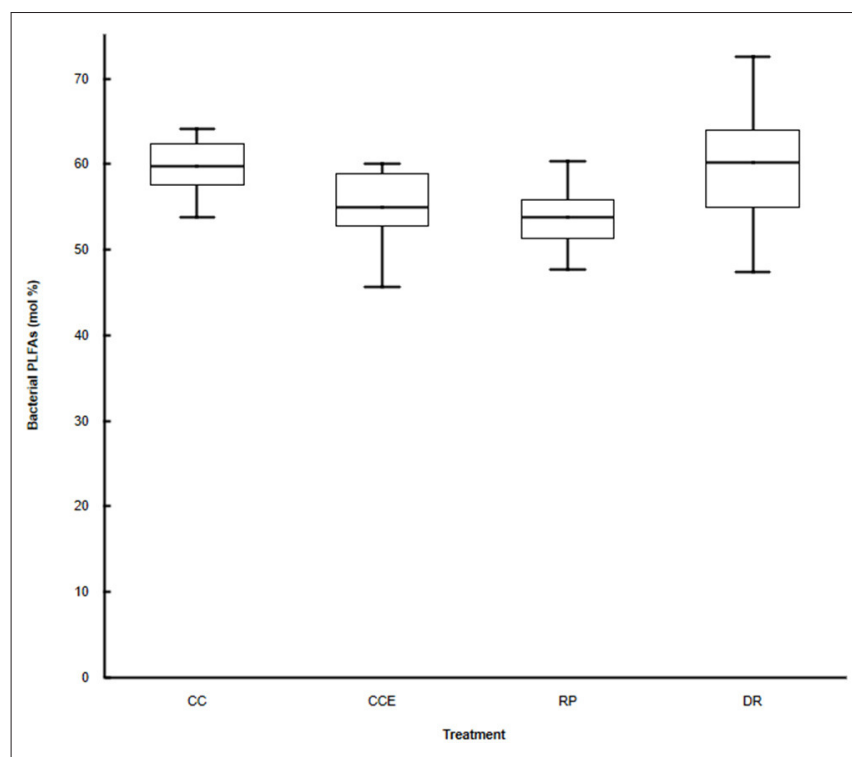

FIGURE 3 | Bacterial abundance (expressed as mol\% bacterial PLFAs) in the dispersed-retention (DR) treatment, the retention patch (RP), in the clear-cut treatment (CC, $9 \mathrm{~m}$, or more from the retention patch) and in the clear-cut edge treatment (CCE, within $9 \mathrm{~m}$ of the retention patch).

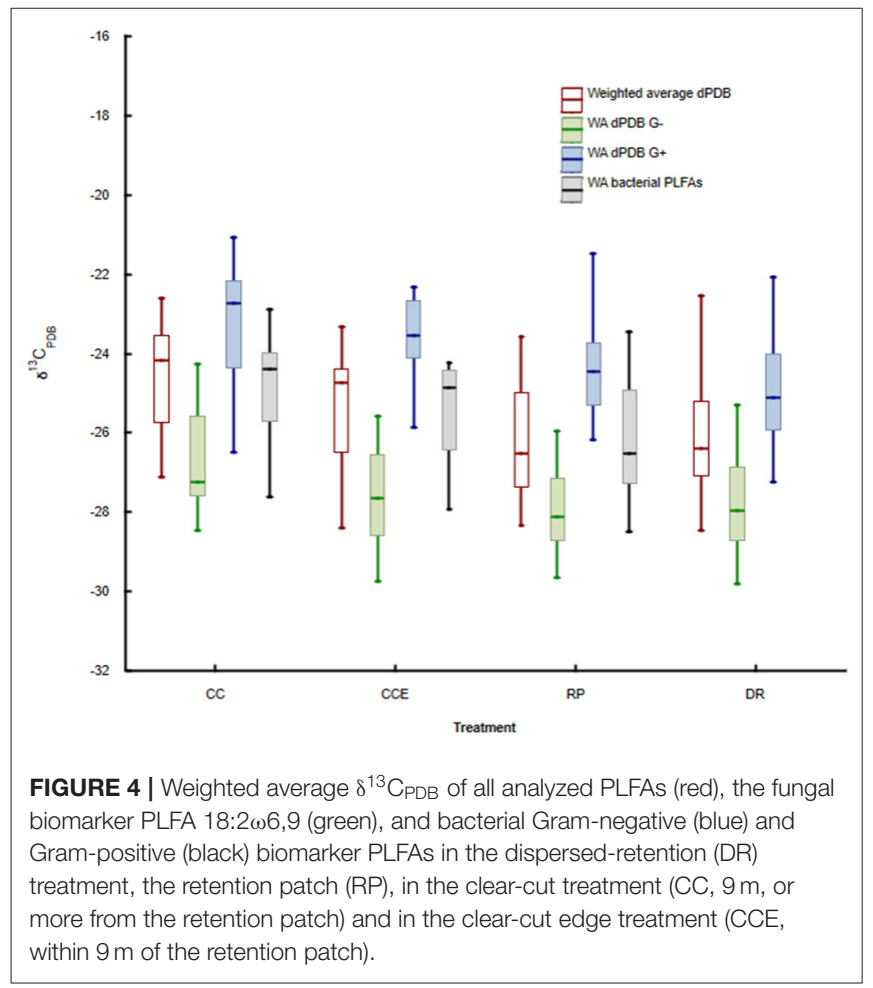

a significant difference between treatments $(H=27.06$, d.f. 3, $p<0.001$, Figure 4), but the following two-tailed comparison of means showed no difference between the dispersed retention treatment and the retention patch. For Gram-positive bacteria the ANOVA showed a significant difference between treatments

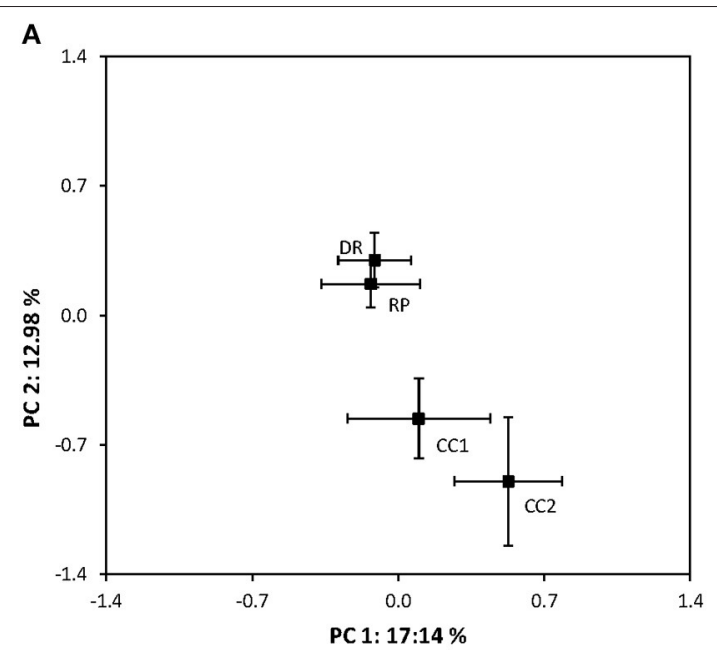

B

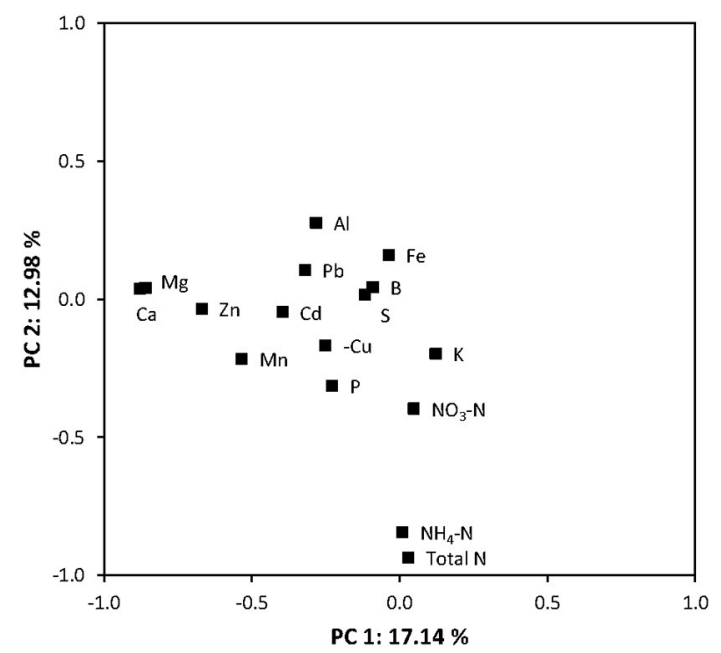

FIGURE 5 | Principal component analysis showing (A) soil nutrient availability based on the concentration of anions and cations adsorbed onto PRS-probes in the dispersed-retention (DR) treatment, the retention patch (RP), in the clear-cut treatment (CC, $9 \mathrm{~m}$, or more from the retention patch) and in the clear-cut edge treatment (CCE, within $9 \mathrm{~m}$ of the retention patch). (B) Relative contributions of individual ions to differences in nutrient availability. Horizontal and vertical error bars represent standard error.

$(\mathrm{H}=32.22$, d.f. $3, p<0.001$, Figure 4), but the following twotailed comparison of means showed no difference between the dispersed retention treatment and the retention patch. For Gramnegative bacteria the ANOVA showed a significant difference between treatments $(\mathrm{H}=13.94$, d.f. $3, p<0.01$, Figure 4), but the following two-tailed comparison of means showed no difference between the dispersed retention treatment and the retention patch.

\section{Nutrient Availability}

The availability of soil nutrients, as indicated by the PRS-probes, was remarkably similar in the dispersed-retention treatment and the retention patch (Figure 5A). Only two nutrients differed in 
TABLE 2 | pH and soil nutrient availability (top $10 \mathrm{~cm}$ ) in the clear-cut treatment, the clear-cut edge treatment (within $9 \mathrm{~m}$ of the retention patch), the retention patch and the dispersed-retention treatment as estimated using PRS probes.

\begin{tabular}{|c|c|c|c|c|c|c|c|c|}
\hline & \multicolumn{2}{|c|}{ Clear-cut } & \multicolumn{2}{|c|}{ Clear-cut edge } & \multicolumn{2}{|c|}{ Retention patch } & \multicolumn{2}{|c|}{ Dispersed retention } \\
\hline & Mean & $\operatorname{SE}(n=30)$ & Mean & $\operatorname{SE}(n=20)$ & Mean & $\operatorname{SE}(n=50)$ & Mean & $\operatorname{SE}(n=100)$ \\
\hline $\mathrm{pH}$ & 3.6 & 0.1 & 3.9 & 0.1 & 3.5 & 0.1 & & \\
\hline Total N & 10.7 & $2.0^{\mathrm{AB}}$ & 9.1 & $1.4^{\mathrm{A}}$ & 5.3 & $0.5^{\mathrm{BC}}$ & 5.6 & $0.9^{C}$ \\
\hline NO3-N & 0.7 & 0.3 & 2.1 & 1.1 & 0.6 & 0.1 & 1.0 & 0.5 \\
\hline $\mathrm{NH} 4-\mathrm{N}$ & 6.5 & $1.9^{A}$ & 2.9 & $0.7^{\mathrm{AB}}$ & 1.3 & $0.4^{\mathrm{BC}}$ & 1.3 & $0.6^{C}$ \\
\hline $\mathrm{Ca}$ & 606.8 & $63.5^{\mathrm{B}}$ & 610.5 & $51.9^{A B}$ & 705.3 & $48.2^{\mathrm{AB}}$ & 837.9 & $40.1^{\mathrm{A}}$ \\
\hline $\mathrm{Mg}$ & 111.4 & $12.9^{\mathrm{B}}$ & 109.3 & $12.7^{\mathrm{AB}}$ & 123.1 & $8.6^{\mathrm{AB}}$ & 150.7 & $7.6^{\mathrm{A}}$ \\
\hline K & 473.5 & $68.3^{\mathrm{A}}$ & 332.2 & $31.3^{\mathrm{A}}$ & 219.3 & 17.7 & 323.4 & $18.9^{\mathrm{A}}$ \\
\hline$P$ & 38.9 & $4.1^{\mathrm{A}}$ & 35.4 & $3.9^{A}$ & 29.6 & $2.7^{\mathrm{AB}}$ & 24.1 & $2.4^{\mathrm{B}}$ \\
\hline $\mathrm{Fe}$ & 5.7 & 0.9 & 4.6 & 0.9 & 5.8 & 0.9 & 4.8 & 0.6 \\
\hline $\mathrm{Mn}$ & 17.5 & $2.3^{\mathrm{B}}$ & 33.2 & $3.8^{\mathrm{A}}$ & 31.8 & $3.6^{\mathrm{A}}$ & 17.8 & $1.3^{\mathrm{B}}$ \\
\hline $\mathrm{Cu}$ & 0.0 & 0.0 & 0.1 & 0.1 & 0.0 & 0.0 & 0.0 & 0.0 \\
\hline $\mathrm{Zn}$ & 1.5 & 0.1 & 1.9 & 0.2 & 1.8 & 0.2 & 1.6 & 0.1 \\
\hline$B$ & 0.1 & $0.0^{\mathrm{AB}}$ & 0.3 & $0.2^{\mathrm{AB}}$ & 0.2 & $0.0^{\mathrm{B}}$ & 0.0 & $0.0^{A}$ \\
\hline S & 16.0 & $1.2^{\mathrm{B}}$ & 13.1 & $1.6^{\mathrm{AB}}$ & 12.7 & $1.0^{\mathrm{AB}}$ & 12.3 & $0.9^{A}$ \\
\hline $\mathrm{Pb}$ & 0.0 & 0.0 & 0.0 & 0.0 & 0.0 & 0.0 & 0.1 & 0.0 \\
\hline $\mathrm{Al}$ & 19.0 & 2.0 & 20.6 & 2.8 & 19.2 & 1.4 & 21.9 & 1.1 \\
\hline $\mathrm{Cd}$ & 0.0 & 0.0 & 0.0 & 0.0 & 0.0 & 0.0 & 0.0 & 0.0 \\
\hline
\end{tabular}

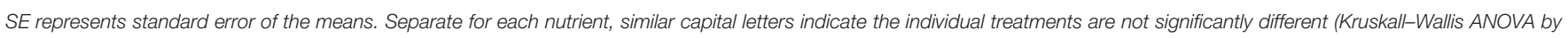
ranks followed by a two-tailed multiple comparison of means, $\alpha>0.05$ ).

availability: $\mathrm{K}$ and Mn (Table 2). Mn concentrations were almost twice as high within the retention patch and at the clear-cut edge treatment compared to the dispersed-retention treatment, whereas $\mathrm{K}$ concentrations were slightly lower within the retention patch compared to the dispersed-retention treatment.

In contrast, the availability of nutrients in the clear-cut edge and clear-cut treatments were significantly different than in the retention patch (Figure 5A, $p<0.001$ ). Most notably $\mathrm{NH}_{4}^{+}$availability was highest in the clear-cut edge and clearcut treatments (Figure 5B, Table 2). There were no differences in concentrations of $\mathrm{NO}_{3}^{-}$between any treatments. Higher concentrations of $\mathrm{K}$ and $\mathrm{P}$ in the clear-cut edge and clear-cut treatments compared to the retention patch were also observed, and the effect was most pronounced in the clear-cut (Figure 5B, Table 2). Concentrations of $\mathrm{Ca}$ and $\mathrm{Mg}$ were higher at the dispersed-retention treatment than in the clear-cut treatment $(p$ $<0.05$ ), and comparisons between the clear-cut edge treatment, the clear-cut treatment, and the retention patch revealed a similar trend (Table 2). Manganese concentration in the clearcut treatment was similar to that at the dispersed-retention treatment; however, it was $45 \%$ higher within the retention patch (Table 2). In contrast, there was no significant difference in Mn concentration between the retention patch and the clear-cut edge treatment.

\section{DISCUSSION}

The aim of variable-retention harvesting is to maintain stand structural diversity and biodiversity associated with mature forests, which includes soil microbial diversity (Franklin et al.,
1997; Beese et al., 2019). In this study, retention of living trees in harvested areas was not successful in preserving the structure of the soil microbial community and activity. Although total microbial biomass was unaffected by harvesting, there was a clear shift in microbial community composition due to clearcutting, even within $9 \mathrm{~m}$ of a retention patch. The differences between the dispersed-retention treatment and the retention patch, clear-cut and clear-cut edge treatments were even more pronounced. The variation was mostly due to a lower abundance

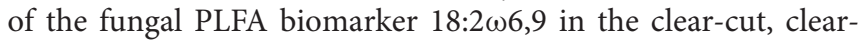
cut edge and dispersed retention treatments, resulting in a microbial community largely dominated by bacteria. However, at the dispersed-retention treatment we also observed a slight shift toward Gram-negative bacterial dominance.

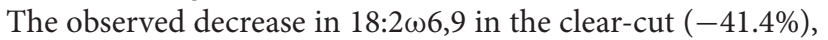
clear-cut edge $(-23.4 \%)$, and dispersed-retention $(-35.1 \%)$ treatments compared to the retention patch, probably indicates reduced abundance of mycorrhizal fungi. Mycorrhizae are dependent on recent tree photosynthates for carbon and so are particularly susceptible to tree harvesting (Hagerman et al., 1999; Byrd et al., 2000; Busse et al., 2006; Hartmann et al., 2009). Girdling studies have shown that removal of recent photosynthates belowground reduces the fungal, and to a lesser extent bacterial communities within weeks (Högberg et al., 2008). Accordingly, Mummey et al. (2010) found that fungal biomass was significantly reduced in grand fir, lodgepole pine, and Douglas-fir forest soils following clear-cutting. Similarly, Luoma et al. (2004), found a decrease in ectomycorrhizal (ECM) sporocarp production in sites with lower stem retention in both aggregated- and dispersed-harvesting regimes. However, other 
studies have shown that the presence of aggregated tree clumps can support mycorrhizal communities up to $10 \mathrm{~m}$ (Jones et al., 2008) and even $20 \mathrm{~m}$ into a clear-cut area through root-exuded C (Churchland et al., 2012).

The low $\delta^{13} \mathrm{C}_{\mathrm{PDB}}$ value of PLFAs in both the retention patch and the dispersed-retention treatment, compared to the clearcut and clear-cut edge treatments, concurs with the fact that recently photosynthesized labile plant $\mathrm{C}$ exuded by roots is typically ${ }^{13} \mathrm{C}$-depleted relative to older $\mathrm{C}$ stored in coarse woody debris and soil organic matter (Kuzyakov, 2006; Werth and Kuzyakov, 2010). This suggests that the microbial community in the clear-cut and clear-cut edge treatments is more reliant on $\mathrm{C}$ sources that are older and more recalcitrant, whereas recently photosynthesized plant $\mathrm{C}$ is a major $\mathrm{C}$ source in the retention patch and at the dispersed-retention treatment. Even if the average $\delta^{13} \mathrm{C}_{\mathrm{PDB}}$ value of microorganisms was similar in the retention patch and in the dispersed-retention treatment, differences in microbial community composition between the two suggest that the recently photosynthesized labile plant $\mathrm{C}$ was utilized by different microorganisms. Mycorrhizal fungi absorb recently photosynthesized $\mathrm{C}$ directly from the tree root and tend to be ${ }^{13} \mathrm{C}$-depleted (Bowling et al., 2008; Churchland et al., 2013). The dispersed-retention treatment had significantly lower

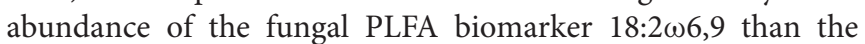
retention patch. Instead, plant $\mathrm{C}$ seemed to be directly utilized by bacteria, particularly Gram-negative bacteria, as suggested by the increased abundance of the Gram-negative biomarker PLFA cy19:0 in the dispersed-retention treatment relative to the retention patch. Accordingly, Gram-negative bacteria are the dominant bacteria associated with the rhizosphere (Paterson, 2003). The decline in mycorrhizal fungal abundance may have allowed the dominant Gram-negative bacteria to access more of the recently photosynthesized $\mathrm{C}$, as also indicated by the lower $\delta^{13} \mathrm{C}_{\mathrm{PDB}}$ value of the Gram-negative PLFA's, resulting in the observed increase in their abundance. Churchland et al. (2012) recently demonstrated through ${ }^{13} \mathrm{C}$-labeling studies of mature tree photosynthate, that fungi and Gram-negative bacteria are the main utilisers of tree root exudate carbon.

Although microbial community composition was significantly altered by the dispersed-retention harvesting, nutrient concentrations remained remarkably similar to those in the uncut patch of retained trees. In contrast, shifts in the microbial community composition in the clear-cut and the clear-cut edge treatments co-occurred with altered nutrient availability. This was most clearly manifested as a five- and two-fold increase in available $\mathrm{NH}_{4}^{+}$concentrations in the clear-cut and clear-cut edge treatments, respectively, compared to both the dispersed retention and retention patch. The different nutrient availability in the dispersed-retention, the clear-cut and clear-cut edge treatments cannot be explained by changes in the microbial biomass, as we found no significant difference in total microbial biomass among these treatments. However, microbial biomass has been shown to respond slowly to environmental change, even when there is up to 10 -fold variation in microbial activity (Bloem et al., 1992; Rousk and Bååth, 2011). The isotopic data suggest that the soil microbes in the clear-cut and clearcut edge treatments may have had less access to labile $\mathrm{C}$ in the form of root exudates, compared to the retention patch and the dispersed-retention treatment, which would reduce microbial activity. Since the quantity and quality of $\mathrm{C}$ often limits microbial growth and activity (Bengtson et al., 2005; Demoling et al., 2007), the greater availability of recent photosynthates would result in more vigorous microbial growth, which in turn would influence the availability and turnover of nutrients (Bengtsson et al., 2003). There are also indications that when the availability of labile plant-C is low, gross $\mathrm{N}$ mineralization exceeds gross $\mathrm{N}$ immobilization, resulting in net mineralization of $\mathrm{N}$, while net immobilization occurs at high availability of labile plant-C (Bengtson et al., 2012). This may explain the low $\mathrm{NH}_{4}^{+}$concentrations in the retention patch and at the dispersed-retention treatment.

The similarity in concentrations of nutrients in the dispersedretention treatment and within the retention patch suggest that dispersed-retention harvesting is effective in avoiding elevated concentrations and potential leaching losses of nutrients such as $\mathrm{N}$ and $\mathrm{K}$. Most studies agree that single-tree retention mitigates $\mathrm{N}$ losses (Hope et al., 2003; Prescott et al., 2003; Redding et al., 2003; Jerabkova et al., 2011). Our results suggest that dispersedretention harvesting that retains as few as 40 trees $^{-1}$, is sufficient to maintain pre-harvest $\mathrm{N}$ availability. In contrast, clear-cutting resulted in elevated $\mathrm{NH}_{4}^{+}$availability. Proximity to a retention patch did not affect $\mathrm{N}$ availability in our study, unlike previous studies (Theil and Perakis, 2009).

Taken together, our results suggest that as long as the microbial community has access to recent plant $\mathrm{C}$, as was the case in the dispersed-retention treatment, the functions which the microbial community provides in terms of nutrient cycling remain largely unchanged after harvest. This indicates that these particular functions are generic-i.e., as long as the total microbial biomass and activity remains the same, decomposition and nutrient cycling will not be greatly affected by shifts in microbial community composition. There was, however, one major exception. The $\mathrm{Mn}^{2+}$ concentration, as determined by PRS-probes, was almost twice as high in the retention patch (and in the clear-cut edge treatment) compared to the dispersed-retention and the clear-cut treatments. This may be related to the low abundance of ectomycorrhizal fungi in the dispersed-retention and in the clear-cut treatments. Manganese is only soluble in its reduced state (Schwab and Lindsay, 1983). It has been demonstrated that the abundance of Mnreducing bacteria is several times higher in the rhizosphere of plants colonized by arbuscular mycorrhizae compared to nonmycorrhizal plants, resulting in higher concentrations of soluble Mn (Nogueira et al., 2007). To our knowledge there have been no studies designed to test if ectomycorrhizae have the same stimulatory effect on Mn-reducing bacteria, but our results suggest that this may be the case. Manganese reduction is only performed by a few specialized microorganisms. Therefore, even though dispersed-retention harvesting methods are successful in preserving generic soil functions, specialist functions are more responsive to changes in microbial community composition. An alternative explanation to the reduced Mn concentrations in the dispersed-retention and the clear-cut treatments is that the fungal communities in these two areas were dominated by saprotrophic 
fungi growing on woody debris and partly decomposed litter. Manganese peroxidase $(\mathrm{MnP})$ is the most common ligninmodifying enzyme produced by white-rot fungi and other wood and litter decomposing basidiomycetes (Hofrichter, 2002). Manganese peroxidase catalyzes the oxidation of soluble $\mathrm{Mn}^{2+}$ to highly reactive $\mathrm{Mn}^{3+}$, which effectively removes the $\mathrm{Mn}$ from the soil solution.

In conclusion, our results demonstrate that harvesting of trees influences the soil microbial community composition, alters the microbial communities' access to labile $\mathrm{C}$ sources, and affects soil nutrient availability. The presence of a retention patch did not appear to lessen the impact of harvesting on soil microbial community structure or nutrient availability in the clear-cut, or clear-cut edge. In contrast, dispersed-retention harvesting seemed to mitigate the effects of harvesting on nutrient cycling, as demonstrated by the remarkably similar concentration of nutrients in this treatment relative to the retention patch. Dispersed-retention harvesting appears to be the most effective variable-retention-harvesting system to maintain microbial functioning and nutrient cycling. Shifts in the microbial community composition in response to harvesting at the dispersed-retention site did not have a major impact on microbial functioning and nutrient availability. However, this may only be true for generic functions/processes; other "narrow" processes (those performed by a small number of specialized microorganisms) such as manganese reduction or lignin degradation, may be more sensitive.

\section{DATA AVAILABILITY STATEMENT}

The raw data supporting the conclusions of this article will be made available by the authors, without undue reservation.

\section{REFERENCES}

Atwell, R. C., Schulte, L. A., and Palik, B. J. (2008). Songbird response to experimental retention harvesting in red pine (Pinus resinosa) forests. For. Ecol. Manage. 255, 3621-3631. doi: 10.1016/j.foreco.2008.02.049

Aubry, K. B., Halpern, C. B., and Peterson, C. E. (2009). Variable-retention harvests in the Pacific Northwest: a review of short-term findings from the DEMO study. For. Ecol. Manage. 258, 398-408. doi: 10.1016/j.foreco.2009.03.013

Bach, L. H., Grytnes, J.-A., Halvorsen, R., and Ohlson, M. (2013). Effects of Tree Removal on Spatial Patterns of Soil Microbial Community Structure. (dissertation/doctoral thesis), Norwegian University of Life Sciences, Oslo (Norway).

Bardgett, R. D., Bowman, W. D., Kaufmann, R., and Schmidt, S. K. (2005). A temporal approach to linking aboveground and belowground ecology. Trends Ecol. Evol. 20, 634-641. doi: 10.1016/j.tree.2005.08.005

Barg, A. K., and Edmonds, R. L. (1999). Influence of partial cutting on site microclimate, soil nitrogen dynamics, and microbial biomass in douglas-fir stands in western Washington. Can. J. For. Res. 29, 705-713. doi: $10.1139 /$ x99-045

Bauhus, J., and Bartsch, N. (1995). Mechanisms for carbon and nutrient release and retention in beech forest gaps. Plant Soil 168, 585-592. doi: $10.1007 / \mathrm{BF} 00029372$

Beese, W. J., Deal, J., Dunsworth, B. G., Mitchell, S. J., and Philpott, T. J. (2019). Two decades of variable retention in British Columbia: a review of its implementation and effectiveness for biodiversity conservation. Ecol. Process. 8:33. doi: 10.1186/s13717-019-0181-9

\section{AUTHOR CONTRIBUTIONS}

SG conceived and obtained funding for this research study. CC undertook the research as part of her Ph.D., dissertation in collaboration with PDF, PB. CC wrote the first draft of the manuscript together with $\mathrm{PB}$. SG and CP contributed to the writing and editing of the manuscript.

\section{FUNDING}

This work was funded through NSERC Strategic and Discovery grants to SG and an NSERC CGSD Award to CC and a Swedish Research Council grant (6212007-3740) and FORMAS grant (2012-1541) awarded to $\mathrm{PB}$.

\section{ACKNOWLEDGMENTS}

We would like to thank Dr Alice Chang for stable-isotope analyses at UBC, Mindy Chow, and Gladys Oka for assistance in the field and laboratory, Dave Goldie (BC Ministry of Forests, Lands, and Natural Resource Operations) for valuable help in the field, and Dr Louise de Montigny (BC Ministry of Forests, Lands, and Natural Resource Operations) for use of the STEMS long-term research facility. This manuscript includes content which first appeared in the Ph.D. thesis of Churchland (2013). This represents the only medium the work has appeared in, and is in line with the University of British Columbia policy, and the thesis can be accessed online.

Bengtson, P., Barker, J., and Grayston, S. J. (2012). Evidence of a strong coupling between root exudation, $\mathrm{C}$ and $\mathrm{N}$ availability, and stimulated SOM decomposition caused by rhizosphere priming effects. Ecol. Evol. 2, 1843-1852. doi: $10.1002 /$ ece 3.311

Bengtson, P., Falkengren-Grerup, U., and Bengtsson, G. (2005). Relieving substrate limitation-soil moisture and temperature determine gross $\mathrm{N}$ transformation rates. Oikos 111, 81-90. doi: 10.1111/j.0030-1299.2005.13800.x

Bengtson, P., Falkengren-Grerup, U., and Bengtsson, G. (2006). Spatial distributions of plants and gross $\mathrm{N}$ transformation rates in a forest soil. J. Ecol. 94, 754-764. doi: 10.1111/j.1365-2745.2006.01143.x

Bengtsson, G., Bengtson, P., and Mansson, K. F. (2003). Gross nitrogen mineralization-, immobilization-, and nitrification rates as a function of soil C/N ratio and microbial activity. Soil Biol. Biochem. 35, 143-154. doi: 10.1016/S0038-0717(02)00248-1

Bever, J. D., Westover, K. M., and Antonovics, J. (1997). Incorporating the soil community into plant population dynamics: the utility of the feedback approach. J. Ecol. 85, 561-573. doi: 10.2307/2960528

Bligh, E. G., and Dyer, W. J. (1959). A rapid method of total lipid extraction and purification. Can. J. Biochem. Physiol. 37, 911-917. doi: 10.1139/o59-099

Bloem, J., de Ruiter, P. C., Koopman, G. J., Lebbink, G., and Brussaard, L. (1992). Microbial numbers and activity in dried and rewetted arable soil under integrated and conventional management. Soil Biol. Biochem. 24, 655-665. doi: 10.1016/0038-0717(92)90044-X

Bock, M. D., and van Rees, K. C. J. (2002). Forest harvesting impacts on soil properties and vegetation communities in the northwest territories. Can. J. For. Res. 32, 713-724. doi: 10.1139/x02-014 
Bowling, D. R., Pataki, D. E., and Randerson, J. T. (2008). Carbon isotopes in terrestrial ecosystem pools and $\mathrm{CO}_{2}$ fluxes. New Phytol. 178, 24-40. doi: 10.1111/j.1469-8137.2007.02342.x

Bradley, R. L., and Parsons, W. F. J. (2007). Net and gross mineral N production rates at three levels of forest canopy retention: evidence that $\mathrm{NH}_{4}^{+}$and $\mathrm{NO}_{3}^{-}$dynamics are uncoupled. Biol. Fertil. Soil 43, 599-602. doi: $10.1007 /$ s00374-006-0138-x

Bradley, R. L., Titus, B. D., and Hogg, K. (2001). Does shelterwood harvesting have less impact on forest floor nutrient availability and microbial properties than clearcutting? Biol. Fertil. Soil 34, 162-169. doi: 10.1007/s0037401 00389

Buée, M., Vairelles, D., and Garbaye, J. (2005). Year-round monitoring of diversity and potential metabolic activity of the ectomycorrhizal community in a beech (Fagus silvatica) forest subjected to two thinning regimes. Mycorrhiza 15, 235-245. doi: 10.1007/s00572-004-0313-6

Busse, M. D., Beattie, S. E., Powers, R. F., Sanchez, F. G., and Tiarks, A. E. (2006). Microbial community responses in forest mineral soil to compaction, organic matter removal, and vegetation control. Can. J. For. Res. 36, 577-588. doi: 10.1139/x05-294

Byrd, K. B., Parker, V. T., Vogler, D. R., and Cullings, K. W. (2000). The influence of clear-cutting on ectomycorrhizal fungus diversity in a lodgepole pine (Pinus contorta) stand, Yellowstone National Park, wyoming, and gallatin national forest, Montana. Can. J. Bot. 78, 149-156. doi: 10.1139/cjb-7 8-2-149

Carlson, D. W., and Groot, A. (1997). Microclimate of clear-cut, forest interior, and small openings in trembling aspen forest. Agric. For. Met. 87, 313-329. doi: 10.1016/S0168-1923(95)02305-4

Carmosini, N., Devito, K. J., and Prepas, E. E. (2002). Gross nitrogen transformation in harvested and mature aspen-conifer mixed forest soils from the boreal plain. Soil Biol. Biochem. 34, 1949-1951. doi: 10.1016/S0038-0717(02)00172-4

Chatterjee, A., Vance, G. F., Pendall, E., and Stahl, P. D. (2008). Timber harvesting alters soil carbon mineralization and microbial community structure in coniferous forests. Soil Biol. Biochem. 40, 1901-1907. doi: 10.1016/j.soilbio.2008.03.018

Chen, J. Q., Franklin, J. F., and Spies, T. A. (1995). Growing-season microclimatic gradients from clear-cut edges into old-growth douglas-fir forests. Ecol. Appl. 5, 74-86. doi: 10.2307/1942053

Churchland, C., Grayston, S. J., and Bengtson, P. (2013). Spatial variability of soil fungal and bacterial abundance: consequences for carbon turnover along a transition from a forested to clear-cut site. Soil Biol. Biochem. 63, 5-13. doi: 10.1016/j.soilbio.2013.03.015

Churchland, C., Weatherall, A., Briones, M. J. I., and Grayston, S. J. (2012). Stableisotope labeling and probing of recent photosynthates into respired $\mathrm{CO}_{2}$, soil microbes and soil mesofauna using a xylem and phloem stem-injection technique on Sitka spruce (Picea sitchensis). Rapid Comm. Mass Spectrom. 26, 2493-2501. doi: 10.1002/rcm.6368

Churchland, C. T. (2013). Green Tree Retention Harvesting as a Tool to Maintain Soil Microbial Diversity and Functioning in Harvested Forests. (Ph.D. thesis), University of British Columbia, Vancouver, BC. Available online at: https:// open.library.ubc.ca/cIRcle/collections/ ubctheses/24/items/1.0074004

Covington, W. W. (1981). Changes in forest floor organic matter and nutrient content following clear cutting in northern hardwoods. Ecology 62, 41-48. doi: $10.2307 / 1936666$

de Montigny, L., Eriksen, R., Strimbu, V., Goldie, D., and Hooper, T. (2018). Silviculture Treatments for Ecosystem Management in the Sayward (Stems): Establishment and Progress Report for Stems 3. Technical Report. Victoria, BC. Availble online at: https://www.for.gov.bc.ca/hfd/pubs/Docs/Tr/TR114.pdf

de Montigny, L. E. (2004). Silviculture Treatments for Ecosystem Management in the Sayward (STEMS): Establishment Report for STEMS 1, Snowden Demonstration Forest. Technical Report. Victoria, BC: BC Ministry of Forests.

Demoling, F., Figueroa, D., and Bååth, E. (2007). Comparison of factors limiting bacterial growth in different soils. Soil Biol. Biochem. 39, 2485-2495. doi: 10.1016/j.soilbio.2007.05.002

Denslow, J. S., Ellison, A. M., and Sanford, R. E. (1998). Treefall gap size effects on above- and below-ground processes in a tropical wet forest. J. Ecol. 86, 597-609. doi: 10.1046/j.1365-2745.1998.00295.x
Entry, J. A., Stark, N. M., and Lowenstein, H. (1986). Effect of timber harvesting on microbial biomass fluxes in a northern rocky mountain forest soil. Can. J. For. Res. 16, 1076-1081. doi: 10.1139/x86-186

Fisk, M. C., and Fahey, T. J. (1990). Nitrification potential in the organic horizons following clearfelling of northern hardwood forests. Soil Biol. Biochem. 22, 277-279. doi: 10.1016/0038-0717(90)90098-K

Franklin, J. F., Berg, D. R., Thornburgh, D. A., and Tappeiner, J. C. (1997) "Alternative silviculture approaches to timber harvesting: variable retention harvest systems," in Creating a Forestry for the 21st Century, eds K. A. Kohm and J. F. Franklin (Washington, DC: Island Press), 111-140.

Franklin, J. F., Johnson, K. N., and Johnson, D. L. (2018). Ecological Forest Management. Long Grove, IL: Waveland Press Inc.

Frostegård, A., Bååth, E., and Tunlid, A. (1993). Shifts in the structure of soil microbial communities in limed forests as revealed by phospholipid fatty-acid analysis. Soil Biol. Biochem. 25, 723-730. doi: 10.1016/0038-0717(93)90113-P

Frostegård, A., Tunlid, A., and Bååth, E. (1991). Microbial biomass measured as total lipid phosphate in soils of different organic content. J. Microbiol. Meth. 14, 151-163. doi: 10.1016/0167-7012(91)90018-L

Futter, M. N., Ring, E., Högbom, L., Entenmann, S., and Bishop, K. H. (2010). Consequences of nitrate leaching following stem-only harvesting of Swedish forests are dependent on spatial scale. Env. Poll. 158, 3552-3559. doi: 10.1016/j.envpol.2010.08.016

Gordon, A. M., and Van Cleve, K. (1983). "Seasonal patterns of nitrogen mineralization following harvesting in the white spruce forests of interior Alaska," in Proceedings of Resource and Dynamics of the Boreal Zone. Thunder Bay, ON: August.

Gravelle, J. A., Ice, G., Link, T. E., and Cook, D. L. (2009). Nutrient concentration dynamics in an inland Pacific Northwest watershed before and after timber harvest. For. Ecol. Manage. 257, 1663-1675. doi: 10.1016/j.foreco.2009.01.017

Gustafsson, L., Baker, S. C., Bauhus, J., Beese, W. J., Brodie, A., Kouki, J., et al. (2012). Retention forestry to maintain multifunctional forests: a world perspective. BioScience 62, 633-645. doi: 10.1525/bio.2012.62.7.6

Hagerman, S. M., Jones, M. D., Bradfield, G. E., Gillespie, M., and Sakakibara, S. (1999). Ectomycorrhizal colonization of Picea engelmannii x Picea glauca seedlings planted across cut blocks of different sizes. Can. J. For. Res. 29, 1856-1870. doi: 10.1139/x99-175

Hangs, R. D., Greer, K. J., and Sulewski, C. A. (2004). The effect of interspecific competition on conifer seedling growth and nitrogen availability measured using ion-exchange membranes. Can. J. For. Res. 34, 754-761. doi: $10.1139 / \mathrm{x} 03-229$

Hannam, K. D., Quideau, S. A., and Kishchuk, B. E. (2006). Forest floor microbial communities in relation to stand composition and timber harvesting in northern Alberta. Soil Biol. Biochem. 38, 2565-2575. doi: 10.1016/j.soilbio.2006.03.015

Hartmann, M., Howes, C. G., VanInsberghe, D., Yu, H., Bachar, D., Christen, R., et al. (2012). Significant and persistent impact of timber harvesting on soil microbial communities in Northern coniferous forests. ISME J. 6, 2199-2218. doi: 10.1038 /ismej.2012.84

Hartmann, M., Lee, S., Hallam, S. J., and Mohn, W. W. (2009). Bacterial, archaeal and eukaryal community structures throughout soil horizons of harvested and naturally disturbed forest stands. Env. Microbiol. 11, 3045-3062. doi: 10.1111/j.1462-2920.2009.02008.x

Hassett, J. E., and Zak, D. R. (2005). Aspen harvest intensity decreases microbial biomass, extracellular enzyme activity and soil nitrogen cycling. Soil Sci. Soc. Am. J. 69, 227-235. doi: 10.2136/sssaj2005.0227

Hernesmaa, A., Björklöf, K., Kiikkilä, O., Fritze, H., Haahtela, K., and Romantschuk, M. (2005). Structure and function of microbial communities in the rhizosphere of scots pine after tree-felling. Soil Biol. Biochem. 37, 777-785. doi: $10.1016 /$ j.soilbio.2004.10.010

Hofrichter, M. (2002). Review: lignin conversion by manganese peroxidase (MnP). Enz. Microb. Technol. 30, 454-466. doi: 10.1016/S0141-0229(01)00528-2

Högberg, P., Högberg, M. N., Göttlicher, S. G., Betson, N. R., Keel, S. G., Metcalfe, D. B., et al. (2008). High temporal resolution tracing of photosynthate carbon from the tree canopy to forest soil microorganisms. New Phytol. 177, 220-228. doi: 10.1111/j.1469-8137.2007.02238.x

Högberg, P., Nordgren, A., Buchmann, N., Taylor, A. F. S., Ekblad, A., Högberg, M. N., et al. (2001). Large-scale forest girdling shows that current 
photosynthesis drives soil respiration. Nature 411, 789-792. doi: 10.1038/350 81058

Hope, G. D., Prescott, C. E., and Blevins, L. L. (2003). Responses of available soil nitrogen and litter decomposition to openings of different sizes in dry interior douglas-fir forests in British Columbia. For. Ecol. Manage. 186, 33-46. doi: 10.1016/S0378-1127(03)00241-X

Jerabkova, L., and Prescott, C. E. (2007). Post-harvest soil nitrate dynamics in aspen- and spruce-dominated boreal forests. For. Ecol. Manage. 242, 209-216. doi: 10.1016/j.foreco.2007.01.003

Jerabkova, L., Prescott, C. E., and Kishchuk, B. E. (2006). Effect of variableretention harvesting on soil nitrogen availability in boreal mixedwood forests. Can. J. For. Res. 36, 3029-3038. doi: 10.1139/x06-175

Jerabkova, L., Prescott, C. E., Titus, B. D., Hope, G. D., and Walters, M. B. (2011). A meta-analysis of the effects of clearcut and variable-retention harvesting on soil nitrogen fluxes in boreal and temperate forests. Can. J. For. Res. 41, 1852-1870. doi: 10.1139/X11-087

Jones, M. D., Durall, D. M., and Cairney, J. W. G. (2003). Ectomycorrhizal fungal communities in young forest stands regenerating after clearcut logging. New Phytol. 157, 399-422. doi: 10.1046/j.1469-8137.2003.00698.x

Jones, M. D., Twieg, B. D., Durall, D. M., and Berch, S. M. (2008). Location relative to a retention patch affects the ECM fungal community more than patch size in the first season after timber harvesting on Vancouver Island, British Columbia. For. Ecol. Manage. 255, 1342-1352. doi: 10.1016/j.foreco.2007. 10.042

Keenan, R. J., and Kimmins, J. P. (1993). The ecological effects of clear-cutting. Env. Rev. 1, 121-144. doi: 10.1139/a93-010

Knight, D. H., Yavitt, J. B., and Joyce, G. D. (1991). Water and nitrogen outflow from lodgepole pine forest after two levels of tree mortality. For. Ecol. Manage. 46, 215-225. doi: 10.1016/0378-1127(91)90233-L

Kranabetter, J. M., and Wylie, T. (1998). Ecotomycorrhizal community structure across forest openings on naturally regenerated western hemlock seedlings. Can. J. Bot. 76, 189-196. doi: 10.1139/cjb-76-2-189

Kropp, B. R., and Albee, S. (1996). The effects of silviculture treatments on occurrences of mycorrhizal sporocarps in a Pinus contorta forest: a preliminary study. Biol. Cons. 78, 313-318. doi: 10.1016/S0006-3207(96) 00140-1

Kroppenstedt, R. M. (1985). "Fatty acid and menaquinone analysis of actinomycetes and related organisms," in Bacterial Systematics, eds M. Goodfellow and D. E. Minnikin (London: Academic Press), 173-200.

Kuzyakov, Y. (2006). Sources of $\mathrm{CO}_{2}$ efflux from soil and review of partitioning methods. Soil Biol. Biochem. 38, 425-448. doi: 10.1016/j.soilbio.2005.08.020

Lajzerowicz, C. C., Walters, M. B., Krasowski, M., and Massicotte, H. B. (2004). Light and temperature differentially colimit subalpine fir and Englemann spruce seedling growth in partial-cut subalpine forests. Can. J. For. Res. 34, 249-260. doi: 10.1139/x03-198

Lapointe, B., Bradley, R. L., and Shipley, B. (2005). Mineral nitrogen and microbial dynamics in the forest floor of clearcut or partially harvested successional boreal forest stands. Plant Soil 271, 27-37. doi: 10.1007/s11104-004-1830-y

Lee, J. Jr, Morrison, I. K., Leblanc, J.-D., Dumas, M. T., and Cameron, D. A. (2002). Carbon sequestration in trees and regrowth vegetation as affected by clearcut, partial harvesting in a second-growth boreal mixedwood. For. Ecol. Manage. 169, 83-101. doi: 10.1016/S0378-1127(02)00300-6

Li, Q. C., Allen, H. L., and Wollum, A. G. (2004). Microbial biomass and bacterial functional diversity in forest soils: effects of organic matter removal, compaction, and vegetation control. Soil Biol. Biochem. 36, 571-579. doi: 10.1016/j.soilbio.2003.12.001

Lindo, Z., and Visser, S. (2003). Microbial biomass, nitrogen and phosphorus mineralization, and mesofauna in boreal conifer and deciduous forest floors following partial and clear-cut harvesting. Can. J. For. Res. 33, 1610-1620. doi: 10.1139/x03-080

Luoma, D. L., Eberhart, J. L., Molina, R., and Amaranthus, M. P. (2004). Response of ectomycorrhizal fungus sporocarp production to varying levels and patterns of green-tree retention. For. Ecol. Manage. 202, 337-354. doi: 10.1016/j.foreco.2004.07.041

Luoma, D. L., Stockdale, C. A., Molina, R., and Eberhart, J. L. (2006). The spatial influence of Pseudotsuga menziesii retention trees on ectomycorrhiza diversity. Can. J. For. Res. 36, 2561-2573. doi: 10.1139/x06-143
Marenholtz, E. H., Lieffers, V. J., and Silins, U. (2010). Evaporative demand across a range of microsites in partial-cut boreal forests. Scan. J. For. Res. 25, 118-126. doi: 10.1080/02827581003730765

Marshall, V. G. (2000). Impacts of forest harvesting on biological processes in northern forest soils. For. Ecol. Manage. 133, 43-60. doi: 10.1016/S0378-1127(99)00297-2

Mladenoff, D. J. (1987). Dynamic of nitrogen mineralization and nitrification in hemlock and hardwood treefall gaps. Ecology 68, 1171-1180. doi: $10.2307 / 1939201$

Moore-Kucera, J., and Dick, R. P. (2008). PLFA profiling of microbial community structure and seasonal shifts in soils of a douglas-fir chronosequence. Microb. Ecol. 55, 500-511. doi: 10.1007/s00248-007-9295-1

Mummey, D. L., Clarke, J. T., Cole, C. A., O’Connor, B. G., Gannon, J. E., and Ramsey, P. W. (2010). Spatial analysis reveals differences in soil microbial community interactions between adjacent coniferous forest and clearcut ecosystems. Soil Biol. Biochem. 42, 1138-1147. doi: $10.1016 /$ j.soilbio.2010.03.020

National Climate data and information archive. (1971-2000). Upper Campbell Lake Climate Station. Available online at: http://www.climate.weatheroffice. gc.ca/climate_normals/results_e.html?stnID $=219 \&$ lang $=e \& d$ Code $=0 \&$ StationName $=$ CAMPBELL\&SearchType $=$ Contains $\&$ province $=$ ALL\& provBut $=\&$ month $1=0 \&$ month $2=12$ (accessed January 4, 2013).

Nave, L. E., Vance, E. D., Swanston, C. W., and Curtis, P. S. (2010). Harvest impacts on soil carbon storage in temperate forests. For. Ecol. Manage. 259, 857-866. doi: 10.1016/j.foreco.2009.12.009

Nogueira, M. A., Nehls, U., Hampp, R., Poralla, K., and Cardoso, E. J. B. N. (2007). Mycorrhiza and soil bacteria influence extractable iron and manganese in soil and uptake by soybean. Plant Soil 298, 273-284. doi: 10.1007/s11104-007-9379-1

Parsons, W. F. J., Knight, D. H., and Miller, S. L. (1994). Root gap dynamics in lodgepole pine forest: nitrogen transformations in gaps of different size. Ecol. Appl. 4, 354-362. doi: 10.2307/1941939

Paterson, E. (2003). Importance of rhizodeposition in the coupling of plant and microbial productivity. Eur. J. Soil Sci. 54, 741-750. doi: 10.1046/j.1351-0754.2003.0557.x

Ponder, F., and Tardos, M. (2002). Phospholipid fatty acids in forest soil four years after organic matter removal and soil compaction. Appl. Soil Ecol. 19, 173-182. doi: 10.1016/S0929-1393(01)00182-2

Prescott, C. E. (2002). The influence of the forest canopy on nutrient cycling. Tree Physiol. 22, 1193-1200. doi: 10.1093/treephys/22.15-16.1193

Prescott, C. E., Corbin, J. P., and Parkinson, D. (1992). Immobilization and availability of $\mathrm{N}$ and $\mathrm{P}$ in the forest floors of fertilized rocky mountain coniferous forest. Plant Soil 143, 1-10. doi: 10.1007/BF00009123

Prescott, C. E., Hope, G. D., and Blevins, L. L. (2003). Effect of gap size on litter decomposition and soil nitrate concentration in a high-elevation spruce-fir forest. Can. J. For. Res. 33, 2210-2220. doi: 10.1139/x03-152

Qian, P., and Schoenau, J. J. (2002). Availability of nitrogen in solid manure amendments with different C:N ratios. Can. J. Soil Sci. 82, 219-225. doi: 10.4141/S01-018

Redding, T. E., Hope, G. D., Fortin, M.-J., Schmidt, M. G., and Bailey, W. G. (2003). Spatial patterns of soil temperature and moisture across subalpine forest-clearcut edges in the southern interior of British Columbia. Can. J. Soil Sci. 83, 121-130. doi: 10.4141/S02-010

Rosenvald, R., and Lõhmus, A. (2008). For what, when, and where is green-tree retention better than clear-cutting? A review of the biodiversity aspects. For. Ecol. Manage. 255, 1-15. doi: 10.1016/j.foreco.2007.09.016

Rousk, J., and Bååth, E. (2011). Growth of saprotrophic fungi and bacteria in soil. FEMS Microbiol. Ecol. 78, 17-30. doi: 10.1111/j.1574-6941.2011.01106.x

Saetre, P. (1999). Spatial patterns of ground vegetation, soil microbial biomass and activity in a mixed spruce-birch stand. Ecography 22, 183-192. doi: 10.1111/j.1600-0587.1999.tb00467.x

Saetre, P., and Bååth, E. (2000). Spatial variation and patterns of soil microbial community structure in a mixed spruce-birch stand. Soil Biol. Biochem. 32, 909-917. doi: 10.1016/S0038-0717(99)00215-1

Schwab, A. P., and Lindsay, W. L. (1983). The effect of redox on the solubility and availability of manganese in a calcareous soil. Soil Sci. Soc. Am. J. 47, 217-220. doi: 10.2136/sssaj1983.03615995004700020008x 
Schweizer, M., Fear, J., and Cardisch, G. (1999). Isotopic (C-13) fractionation during plant residue decomposition and its implications for soil organic matter studies. Rapid Comm. Mass Spec. 13, 1284-1290. doi: $\quad$ 10.1002/(SICI)1097-0231(19990715)13:13<1284::AID-RCM578>3. $0 . \mathrm{CO} ; 2-0$

Siira-Pietikäinen, A., Pietikäinen, J., Fritze, H., and Haimi, J. (2001). Short-term responses of soil decomposer communities to forest management: clear felling versus alternative forest harvesting methods. Can. J. For. Res. 31, 88-99. doi: $10.1139 / \mathrm{x} 00-148$

Smolander, A., Priha, P., Paavolainen, L., Steer, J., and Mälkönen, E. (1998). Nitrogen and carbon transformations before and after clear-cutting in repeatedly N-fertilized and limed forest soil. Soil Biol. Biochem. 30, 477-490. doi: 10.1016/S0038-0717(97)00141-7

Sundman, V., Huhta, V., and Niemela, S. (1978). Biological changes in northern spruce forest soil after clear-cutting. Soil Biol. Biochem. 10, 393-397. doi: 10.1016/0038-0717(78)90064-0

Teste, F. P., Lieffers, V. J., and Strelkov, S. E. (2012). Ectomycorrhizal community responses to intensive forest management: thinning alters impacts of fertilization. Plant Soil 360, 333-347. doi: 10.1007/s11104-012-1231-6

Theil, A. L., and Perakis, S. S. (2009). Nitrogen dynamics across silvicultural canopy gaps in young forests of western oregon. For. Ecol. Manage. 258, 273-287. doi: 10.1016/j.foreco.2009.04.015

Titus, B. D., Prescott, C. E., Maynard, D. G., Mitchell, A. K., Bradley, R. L., Feller, M. C., et al. (2006). Post-harvest nitrogen cycling in clearcut and alternative silvicultural systems in a montane forest in coastal British Columbia. For. Chron. 82, 844-859. doi: 10.5558/tfc82844-6

Vitousek, P. M., Gosz, J. R., Grier, C. C., Melillo, J. M., Reiners, W. A., and Todd, R. L. (1979). Nitrate losses from disturbed ecosystems. Science 204, 469-474. doi: $10.1126 /$ science.204.4392.469

Wardle, D. A., Bardgett, R. D., Klironomos, J. N., Setala, H., van der Putten, W. H., and Wall, D. H. (2004). Ecological linkages between aboveground and belowground biota. Science 304, 1629-1633. doi: 10.1126/science.1094875
Werth, M., and Kuzyakov, Y. (2010). C-13 fractionation at the rootmicroorganisms-soil interface: a review and outlook for partitioning studies. Soil Biol. Biochem. 42, 1372-1384. doi: 10.1016/j.soilbio.2010. 04.009

White, D. C., Davis, W. M., Nickels, J. S., King, J. D., and Bobbie, R. J. (1979). Determination of the sedimentary microbial biomass by extractable lipid phosphate. Oecology 40, 51-62. doi: 10.1007/BF003 88810

Work, T. T., Spence, J. R., Volney, W. J. A., Morgantini, L. E., and Innes, J. L. (2003). Integrating biodiversity and forestry practices in western Canada. For. Chron. 79, 906-916. doi: 10.5558/tfc79906-5

Zak, D. R., Holmes, W. E., Finzi, A. C., Norby, R. J., and Schlesinger, W. H. (2003). Soil nitrogen cycling under elevated $\mathrm{CO}_{2}$ : a synthesis of forest face experiments. Ecol. Appl. 13, 1508-1514. doi: 10.1890/0 3-5055

Zogg, G. P., Zak, D. R., Ringelberg, D. B., MacDonald, N. W., Pregitzer K. S., and White, D. C. (1997). Compositional and functional shifts in microbial communities due to soil warming. Soil Sci. Soc. Am. J. 61, 475-481. doi: 10.2136/sssaj1997.0361599500610002 $0015 \mathrm{x}$

Conflict of Interest: The authors declare that the research was conducted in the absence of any commercial or financial relationships that could be construed as a potential conflict of interest.

Copyright $\odot 2021$ Churchland, Bengtson, Prescott and Grayston. This is an openaccess article distributed under the terms of the Creative Commons Attribution License (CC BY). The use, distribution or reproduction in other forums is permitted, provided the original author(s) and the copyright owner(s) are credited and that the original publication in this journal is cited, in accordance with accepted academic practice. No use, distribution or reproduction is permitted which does not comply with these terms. 